\title{
Recruiting consultants
}

\author{
David Storer
}

Market forces can solve most problems as long as the market place is free enough of restrictive practices to allow those forces free reign. Such has been the dominant political philosophy of recent times and we are told that the "Health Care Sector" is no different from any other area of business.

It is to be expected, therefore, that given the competition currently pertaining in the field of consultant appointments that the sellers of jobs (mainly NHS trusts) would be suitably entrepreneurial in marketing their posts. Some trusts are spending large sums in using recruitment agencies to carry out this task although it is not clear where the expertise of these agencies lies.

The survey reported in this month's Bulletin by Mactler \& Khoosal, therefore, may come as a surprise to some. It indicates that many trusts are making a poor attempt at making their posts attractive and of informing potential applicants of their merits. One would at least expect 'Directors of Human Resources' and medical directors to produce an attractive package of information and to reply promptly and personally.

However, perhaps of even more importance is the content of the job descriptions. Rodger \& Wattis (1995) compared consultant job descriptions in old age psychiatry with College guidelines and found a generally poor standard. College regional advisers see a wide range of job descriptions, some of which contain a great deal of jargon and little information while others offer few resources and propose excessive work-loads.

Medical directors need to be aware that first impressions are important and should ensure that their trusts are presenting themselves professionally. They will be far more in tune with the needs of potential applicants than recruitment agencies, so by working with their personnel departments can save a great deal of money which could be better spent on clinical services and can produce an attractive package for applicants.

Those seeking posts, on the other hand, are in a strong position and should feel able to discuss their own expectations from a consultant post with potential future colleagues and to clarify. and if necessary negotiate changes to, any doubtful parts of the job description.

\section{References}

MACTIER, F. \& KHOOSAL, D. (1997) Essential information for filling consultant posts. Psychiatric Bulletin, 21. 4-5.

RODGER, C. R. \& WATnS. J. P. (1995) Job descriptions for consultant posts in psychiatry of old age. Psychiatric Bulletin, 19, 96-98.

David Storer, Chairman of College Manpower Committee, and Consultant Psychiatrist, Leeds General Infirmary, Great George Street, Leeds LS1 3EX 